https://doi.org/10.29013/ESR-19-9.10-95-97

Serebrennikova Anna Valerievna, Doctor of law, Professor of criminal law and criminology Moscow state University. M. V. Lomonosov

Russia, Moscow

E-mail:serebranna@hotmail.com

Lebedev Maxim Vladimirovich, Postgraduate student, Department of criminal law and criminology Moscow state University M. V. Lomonosov, Russia, Moscow E-mail:3g4g@mail.ru

\title{
PREVENTION OF THE FINANCING OF TERRORISM: CURRENT ISSUES IN THEORY AND PRACTICE OF APPLICATION IN THE RUSSIAN FEDERATION
}

\begin{abstract}
Urgency of the terrorism financing research is caused by the fact that terroristic activities currently is one of the most severe threats for national security of Russian Federation. As of today, within the Russia territory, in the на post-Soviet area including CIS, and in the near abroad countries terroristic organizations and groups, along with individual criminals are still active. Danger to the public raised by terrorist acts is caused by their by their large scales, cruel results, large numbers of victims, destabilizing effect for all spheres of public interest. When analyzing the problems of terrorism financing, the authors considered judicial practice using specific criminal cases, genesis dynamics of norms providing for criminal liability for this group of crimes, and discovered a number of imperfections, errors, and gaps in the current legislation.

Keywords: Russian Federation, Criminal Code, terrorist act, terrorist financing, criminal liability.

In compliance with Item 1 of the Concept of Terrorism Suppressing in RF approved by the RF President on 10/05/2009, one of the main tendencies of the present-day terrorism is raising the level of terroristic activity financing along with maintenance supply of terroristic organizations. Besides, one of the main external factors facilitating formation and spread of terrorism in our country is financial support of Russian terroristic formations by international terroristic organizations. Thereupon, the main measures against terrorism (for its prevention), along with political, social, and economic efforts, include also legal ones (legislation improvement and practical implementation of the punishment unavoidability principle including for terrorism financing).

However, the number of detected terrorism financing facts in Russia, as compared with the overall growth of terroristic crime organization, still remains extremely low. For example, according to judicial statistic data of the Justice Department at the RF Supreme Court, in the period since 2007 till 2011 , only 18 crimes were disclosed, while since 2012 till the first half of 2019148 crimes were investigated successfully. According to statistics, 49 persons were sentenced for crimes (the main accusation) under Art. 205.1 of the RF Criminal Code, while 24 ones received accumulative sentences. Besides, nobody was convicted, in these periods, under Part 2 of this Article, while 3 persons were sentenced under the Part 3 of the
\end{abstract}


main Article, and other 4 persons received accumulative sentences.

The legal base of the terrorism financing suppression includes, apart from RF international treaties, RF Constitution, RF Criminal Code, Federal Laws dd. 08/07/2001, N115-FZ, "On Measures Against Illegal Profit Legalization (Laundering) and Terrorism Financing", and dd. 03/06/2006, N35-FZ, "On Measures Against Terrorism”, RF Government orders and instructions, and also regulatory acts of RF Central Bank and Rosfinmonitoring (FSFM).

Persons abusing their official positions shall include both officials and government and municipal employees that are not officials, along with those who, permanently, temporary, or under a special authority, are performing organizational/management or administrative duties in a business organization of any pattern of ownership or a non-profit entity that is not a state or municipal institution [3]. Abuse of any official position when committing crimes under Art. 205.1 of the RF Criminal Code shall be considered not only as intentional abusing one's official position but also as exerting an impact, depending on importance and prestige of the occupied position, on other persons for motivation them to perform actions encouraging terroristic activities.

It should be noted that, in compliance with the note to Art. 205.1 of the RF Criminal Code, a criminal may be release from criminal liability if he/she prevented the crime commitment by informing in due time the official authorities or assisting in another way in prevention or suppression of the crime that he/she had financed and/or assisted to commit provided his/her activities include no other components of the crime[1].

In the next Revision No. 46 dd. 07/06/2016, the legislator made an amendment associated with identification of legal entity beneficiary owners. For example, Art. 6.1 "Legal Entity Duties Regarding Disclosure of its Beneficiary Owners" was added to Art. 6. Under this amendment, legal entities are obliged to: keep information about their beneficiary owners, identify them, regularly, at least once (a year, a month, a week - a gap in the text - translator's comment) amend the information about their beneficiary owners and fix acquired information in documents. Besides, the information about beneficiary owners and measures for their identification and collection of respective information shall be kept. The legal entity shall provide the acquired and confirmed by documents information about its beneficiary owners to an authorized body, tax agency, or other federal body of executive authorities authorized by the Russian Federation Government under their requests.

In conclusion, the legislator shall explain the concept of beneficiary owner, that is a natural person that is, eventually, a direct or indirect (via third parties) owner (having a dominant participation of over $25 \%$ in the capital) of a legal entity or may control its activities.

Having acquired such information, we may suppose the legislator thus is performing regular activities for identification of shadow financial flows that may also be used for terrorism financing [4].

The analysis carried out makes it possible to highlight a number of problems complicating identification and suppression of terrorism financing cases:

1. High latency of crimes caused by local population being afraid of cooperation with the law-enforcement authorities, especially in highly criminogenic areas, such as, for example, North Caucasian Federal District.

2. Insufficient level of employee competence in law enforcement authorities, especially in the mentioned areas.

3. Problems in performing operational search actions among local inhabitants because of their ethnic and confessional solidarity.

4. Problems of evidence collection.

5. High level of criminal organization and maintenance supplies of terroristic groups.

6. Secret preparation of terrorist acts and limited number of informed persons.

7. Shortcomings of active money laundering legislation. 
8. Inefficient control of financial flows between doubtful contracting parties all listed above impedes efficient suppression of terrorist acts.

Identifying and blocking efficiently channels of terroristic organization financial support is one of the most important and, at the same time, complex prob- lems to be resolved by world society within the scope of joint efforts for suppression of this global threat. Thus, it seems important to continue taking respective measures aimed to enhance coordination of special services in their struggle against terrorism financing and development of Russian legislation in this area.

\section{References:}

1. Comment to the Criminal Code of Russian Federation (part-by-part) / G. N. Borzenkov, A. V. Brilliantov, A. V. Galakhova [et al]; editor-in-chief: B. M. Lebedev. - M., 2013.

2. Kurbanov R.A. Suppression of Money Laundering and Terrorism Financing: Specifics of Legal Regulation at the post-Soviet area. Gaps in Russian legislation, 4: 2016. - P. 252-255.

3. Ruban D. E. Criminal Liability for terrorism financing (theoretical and legal aspects). Gaps in Russian Legislation, 3: 2017. - P. 266-269.

4. Ulyanova V.V. Suppression of Terrorism Financing: Author's abstract, Thesis of PhD in Law.- Yekaterinburg, 2010.- $17 \mathrm{p}$. 